\title{
The Effect of Growth Hormone on Lipid Accumulation or Maturation in Adipocytes
}

\author{
Yuchao Zhang ${ }^{a, b, c}$ Hongsheng Yu ${ }^{d}$ Peng Gao Jicui Chen ${ }^{a}$ Cong Yu Chen Zong ${ }^{a}$ \\ Sumei Lu ${ }^{\mathrm{e}}$ Xia Lia Xiaoli Ma ${ }^{\mathrm{b}}$ Yuantao Liu ${ }^{\mathrm{b}}$ Xiangdong Wanga,f \\ aDepartment of Cell Biology, Shandong University School of Medicine, Jinan, ${ }^{b}$ Department of \\ Endocrinology, Qingdao Municipal Hospital, Qingdao, 'Center for Reproductive Medicine, Provincial \\ Hospital Affiliated to Shandong University, Jinan, ${ }^{\mathrm{d} T h e}$ Department of Clinical Laboratory, the Affiliated \\ Hospital of Ningbo University School of Medicine, Ningbo, eDepartment of Laboratory Medicine, \\ Shandong Provincial Qianfoshan Hospital, Shandong University, Jinan, Shandong, ${ }^{\text {fKey Laboratory of }}$ \\ Protein Sciences for Chronic Degenerative Diseases in Universities of Shandong (Shandong University), \\ Jinan, China
}

\section{Key Words}

Growth hormone $(\mathrm{GH}) \cdot 3 \mathrm{~T} 3-\mathrm{F} 442 \mathrm{~A}$ adipocyte $\cdot \mathrm{GH}$ intervention • Peroxisome proliferatoractivated receptor $\gamma($ PPAR $\gamma) \cdot$ Uncoupling protein-1 (UCP1)

\begin{abstract}
Background: Adipogenesis of adipocytes includes two stages: initiation and maturation. Growth hormone $(\mathrm{GH})$ secretion is decreased in obese subjects and $\mathrm{GH}$ levels are inversely correlated with abdominal fat mass. The effects of growth hormone $(\mathrm{GH})$ on lipids accumulation or maturation of adipocytes remains elusive. Methods: In the present study, effect of GH on lipid accumulation in vitro and in vivo was examined. cDNA microarray, quantitative real timePCR ( $\mathrm{PPCR}$ ) and western blotting was used to analyze the expression of genes related to adipocyte lipid accumulation or degradation in pre- or mature 3T3-F442A adipocytes treated with $\mathrm{GH}$ and in epididymal adipose tissue of $\mathrm{C} 57 \mathrm{BL} / 6$ mice administrated with $\mathrm{GH}$. Level of adiponectin in supernatants of cultured F442A adipocytes was determined by enzymelinked immune-sorbent assay. Results: We found that in 3T3-F442A especially 6 days post initiation of adipogenesis, $\mathrm{GH}$ intervention resulted in decreased expression of adipocyte maturation regulators $(C / E B P \alpha, P P A R Y)$ and prominent genes related to lipid synthesis such as FAS and FABP, while the expression of UCP1 was markedly enhanced. cDNA microarray analysis and qPCR showed that the expression of SOCS2 and Adipor2 was increased under $\mathrm{GH}$-treatment in mature 3T3-F442A adipocytes. GH treatment increased the mRNA expression of adiponectin and UCP1 in mature adipocytes. The above results were confirmed by in vivo study. Conclusions: $\mathrm{GH}$ potentially negatively modulates the maturation and accumulation of lipid in adipocytes.




\section{Cellular Physiology Cell Physiol Biochem 2016;39:2135-2148 \begin{tabular}{ll|l} 
and Biochemistry & Dublished online: November 02, 2016 & $\begin{array}{l}\text { @ 2016 The Author(s). Published by S. Karger AG, Basel } \\
\text { www.karger.com/cpb }\end{array}$ \\
\hline
\end{tabular} Zhang et al.: GH on Lipid Maturation in Adipocytes}

\section{Introduction}

Growth hormone (GH), a 22-kDa polypeptide, is secreted in anterior pituitary gland, exerts important biological and physiologic effects $[1,2]$. Pulsatile GH secretion plays a major role in controlling longitudinal growth in children, and in the human body, GH stimulates protein synthesis at the whole-body level, whereas in muscle tissue it inhibits glucose disposal $[3,4]$. Growth hormone has also been shown to be involved adiposity. In obese subjects, GH secretion is reduced, and GH levels are inversely correlated with abdominal fat mass; GH secretion can be restored after a massive weight loss [5].

GH exerts biological effects directly on target cells by binding to cell membrane receptors (GHR) or/and through insulin-like growth hormone factor-I (IGF-I). The binding of GH to GHR activates the tyrosine kinase Janus kinase 2 (JAK2) and triggers a series of signal pathways including the signal phosphatidylinositol 3-kinase (PI3K), mitogen-activated protein kinase (MAPK) and signal transducer and activator of transcription 5 (STAT5) pathway [6]. GH activates PI3K and ERK signaling pathways similar to that of insulin which is an essential hormone for adipogenesis, therefore, $\mathrm{GH}$ may have similar effects on the initiation and transformation of pre-adipocyte differentiation into adipocyte, as suggested by Doglio and Nixon $[7,8]$. Our previous data showed that insulin has a synergistic effect on GH induced STAT5 activation [9].

Obesity is a chronic metabolic disease due to fat accumulation [10], and is associated with increased risks of vascular diseases, inflammation, metabolic syndrome and type II diabetes $[11,12]$. Obesity can be considered as a hypertrophic disease resulted from an increase in the number or size of individual adipocytes. Adipocytes are differentiated from pre-adipocytes. Under certain conditions, GH acts on adipose tissue to increase lipolysis, leading to the release of free fatty acid (FFA) into the blood in human and rodents [6]. In addition, treatment with GH in patients with growth hormone deficiency decreased fat mass and leptin levels [13]. GH stimulated lipolysis has been demonstrated in animal study [14]. However, GH was also shown to promote adipose differentiation in other studies $[7,8]$. Therefore, the precise effect of GH on the fate of adipocytes needs further investigation. The related mechanism of GH modulating the size of adipocyte or the mass of adipose tissue also needs exploring.

In the present study, we designed a serial of experiments to determine whether GH inhibits adipocyte maturation or lipid accumulation in transformed pre-adipocyte during adipogenesis.

\section{Materials and Methods}

Reagents and antibodies

Cell culture medium and fetal bovine serum (FBS) were from Hyclone (ThermoScientific, Inc., Illinois, USA). Recombinant human GH was kindly provided by Eli Lilly \& Co. (Indianapolis, IN). Primers used in this study were synthesized in Genomics Institute of HuaDa in Beijing. All other reagents were purchased from Sigma (St. Louis, MO, USA). Polyclonal antibody against CCAAT/enhancer binding protein $\alpha(\mathrm{C} / \mathrm{EBP} \alpha)$, peroxisome proliferator-activated receptor $\gamma(\operatorname{PPAR} \gamma)$ was purchased from Santa Cruz Biotechnology, Inc (Santa Cruz, CA); polyclonal antibody against fatty acid synthase (FAS) was from Proteintech Group, Inc (Wuhan, China); monoclonal antibody against $\alpha$-tubulin was from Sigma (St. Louis, MO, USA). All secondary antibodies were purchased from ZhongShanJinQiao, Inc (Beijing, China).

Culture and differentiation of 3T3-F442A pre-adipocytes

The mouse embryo fibroblasts 3T3-F442A were cultured and induced to differentiate as described previously [9]. In brief, cells were cultured in Dulbecco`s modified Eagle`s medium containing (DMEM) $4.5 \mathrm{~g} / \mathrm{L}$ glucose, supplemented with $10 \% \mathrm{FBS}, 50 \mu \mathrm{g} / \mathrm{mL}$ streptomycin and $100 \mathrm{U} / \mathrm{mL}$ penicillin until they reached confluence. To induce differentiation, confluent cells were cultured in DMEM containing 10\% FBS, $10 \mu \mathrm{M}$ insulin, $1 \mu \mathrm{M}$ dexamethasone, and $0.5 \mathrm{mM}$ 3-isobutyl-1-methylxanthine. Medium was changed after 2 days with DMEM containing $10 \%$ FBS and $10 \mu \mathrm{M}$ insulin. Cells were then cultures with DMEM containing 


\section{Cellular Physiology Cell Physiol Biochem 2016;39:2135-2148 \begin{tabular}{ll|l} 
and Biochemistry & $\begin{array}{l}\text { DOI: 10.1159/000447909 } \\
\text { Published online: November 02, } 2016\end{array}$ & $\begin{array}{l}\text { ( ) 2016 The Author(s). Published by S. Karger AG, Basel } \\
\text { www.karger.com/cpb }\end{array}$ \\
\hline
\end{tabular} \\ Zhang et al.: GH on Lipid Maturation in Adipocytes}

10\% FBS every other day. At 12 days, approximately 80\% 3T3-F442A cells were differentiated into adipocytes as confirmed by Oil Red-O staining.

\section{GH treatment in mature adipocytes or GH intervention during the process of adipogenesis}

To investigate the role of GH in the process of adipocyte differentiation, 3T3-F442A pre-adipocytes were treated with $\mathrm{GH}(125 \mathrm{ng} / \mathrm{mL})$ during the whole process of adipogenesis. In order to clarify the role of GH in mature adipocytes, differentiated 3T3-F442A cells were treated with GH (at final concentration of 125 $\mathrm{ng} / \mathrm{mL}$ ). Cells without $\mathrm{GH}$ treatment in both experiments were used as controls.

\section{Animal experiments}

Male C57/BL6 mice, aged 6-weeks, weighing 16-20 g, were purchased from the Experimental Animal Center of Shandong University. Animal experiments were carried out according to the 'Principles of laboratory animal care' established by the National Institutes of Health, and approved by the 'Animal Care and Use Committee' of the Shandong University (Number: MECSDUMS 2011055). Mice were maintained under diurnal lightning conditions at $25^{\circ} \mathrm{C}$ with free access to tap water and food. 20 mice were fed with a high-fat diet containing $20 \%$ fat and 10 mice were fed with normal diet. Animal body weights were monitored once a week until the difference in body weight between high-fat diet and normal diet mice exceeded $30 \%$. These mice with bigger body weight were regarded as obese mice. The obese mice were randomly divided into two groups: the "control group" and "GH group". GH group mice were injected intraperitoneally (i.p.) with $50 \mu \mathrm{g}$ of GH per kg of body weight (BW) in $0.2 \mathrm{ml}$ saline once a week for 12 weeks. The control mice were injected with same volume of saline. Prior to injection, all mice were fasted overnight. Finally, after GH treatment, mice were sacrificed by decapitation under anesthesia with $10 \%$ chloral hydrate. Epididymal adipose tissues were collected for quantitative real-time PCR analysis.

\section{cDNA microarray analysis}

Gene expression profiling was conducted using a microarray chip containing the whole genome array (Boao capital, Beijing, China) for mice (28793 oligoclones). GH treated or non-GH treated 3T3-F442A adipocytes were solubilized in Trizol (Invitrogen, USA) and total RNA was prepared according to the manufacturer`s suggested protocol. RNA samples were reverse transcribed and labeled for microarray analysis using standard techniques. Briefly, total RNA was converted to fluorescently labeled with Cy3 or Cy5 and Superscript II reverse transcriptase in the presence of 2-aminoallyl-dUTP as described previously. Imaging and

image analysis were performed in a LuxScan 10KA scanner (CapitalBio, Beijing, China). Differentially expressed genes were defined as outliers if the calibrated red to green ratio was greater than 2.0 for all genes that had a minimal intensity of 1500 and a maximal intensity of 6000 in either channel.

\section{Quantitative Real-time PCR ( $q$ PCR)}

Total RNA was extracted from treated adipocytes as indicated using Trizol reagent (Takara Bio Inc., Dalian, China) and was reversely transcribed into cDNA using PrimeScript RT reagent Kit With gDNA Eraser (Takara Bio Inc.). The qPCR was performed on a Roche LightCycle 480 (Roche, Penzberg, Germany) with an initial enzyme activation step of 3 min at $95^{\circ} \mathrm{C}$, followed by 40 cycles of two-step PCR ( $95{ }^{\circ} \mathrm{C}$ for $45 \mathrm{sec}$; $60{ }^{\circ} \mathrm{C}, 60$ sec). Primers can be found in Table 1 (Genomics Institute of HuaDa, Beijing, China).

PCR data results were expressed as $\mathrm{Ct}$ values, with $\mathrm{Ct}$ defined as the threshold
Table 1. Sequence information for the primers used for PCR or qPCR

\begin{tabular}{|c|c|c|}
\hline Genes & Primer sequences for qPCR & Size (bp) \\
\hline \multirow[t]{2}{*}{$A T G L$} & 5'-TCCGTGGCTGTCTACTAAAGA-3' & 118 \\
\hline & 5'-TGGGATATGATGACGTTCTCTCC-3' & \\
\hline \multirow[t]{2}{*}{ Adiponectin } & 5'-TGTTCCTCTTAATCCTGCCCA-3' & 104 \\
\hline & 5'-CCAACCTGCACAAGTTCCCTT-3' & \\
\hline \multirow[t]{2}{*}{ Adipor2 } & 5'-GAGTGTTCGTGGGCTTAGG-3' & 143 \\
\hline & 5'- GCAGCTCCGGTGATATAGAGG-3 & \\
\hline \multirow[t]{2}{*}{$C / E B P \alpha$} & 5'-CAAGAACAGCAACGAGTACCG-3' & 124 \\
\hline & 5'-GTCACTGGTCAACTCCAGCAC-3' & \\
\hline \multirow[t]{2}{*}{$F A B P$} & 5'-AAGGTGAAGAGCATCATAACCCT-3' & 133 \\
\hline & 5'-TCACGCCTTTCATAACACATTCC-3' & \\
\hline \multirow[t]{2}{*}{ FAS } & 5'-GGAGGTGGTGATAGCCGGTAT-3' & 141 \\
\hline & 5'-TGGGTAATCCATAGAGCCCAG-3' & \\
\hline \multirow[t]{2}{*}{$H S L$} & 5'-CCAGCCTGAGGGCTTACTG-3' & 106 \\
\hline & 5'-CTCCATTGACTGTGACATCTCG-3' & \\
\hline \multirow[t]{2}{*}{ Leptin } & 5'-GAGACCCCTGTGTCGGTTC-3' & 136 \\
\hline & 5'-CTGCGTGTGTGAAATGTCATTG-3' & \\
\hline \multirow[t]{2}{*}{ PPARY } & 5'-GACCACTCGCATTCCTTT-3' & 360 \\
\hline & 5'-GGCATTGTGAGACATCCC-3' & \\
\hline \multirow[t]{2}{*}{ SOCS2 } & 5'-TCTTTTGGGGTACCCTGTGAC-3' & 303 \\
\hline & 5'-GAAAGTTCCTTCTGGCGCCTCT-3' & \\
\hline \multirow[t]{2}{*}{ UCP1 } & 5'-AGGCTTCCAGTACCATTAGGT-3' & 133 \\
\hline & 5'-CTGAGTGAGGCAAAGCTGATTT-3' & \\
\hline \multirow[t]{2}{*}{$\beta$-Actin } & 5'-GTGACGTTGACATCCGTAAAGA-3' & 245 \\
\hline & 5'- GCCGGACTCATCGTACTCC-3' & \\
\hline
\end{tabular}




\section{Cellular Physiology Cell Physiol Biochem 2016;39:2135-2148 \begin{tabular}{ll|l} 
and Biochemistry $10.1159 / 000447909$ & $\begin{array}{l}\text { O 2016 The Author(s). Published by S. Karger AG, Base } \\
\text { www.karger.com/cpb }\end{array}$ \\
\hline
\end{tabular} \\ Zhang et al.: GH on Lipid Maturation in Adipocytes}

cycle of PCR at which amplified PCR product was first detected. To minimize intra- and inter-assay variability generated from differences in PCR efficiency, the quantity of the target sequence was normalized with $\beta$-Actin mRNA. The threshold value of the target sequence is directly proportional to the absolute concentration when compared with the Ct value for reference genes. The relative mRNA expression level of the target copies was expressed as fold change compared with control as determined by the $2^{-\Delta \Delta \mathrm{Ct}}$ method, a relative quantification algorithm. The factor $(\mathrm{X})$ by which the amount of the changed gene can be calculated with the following formula: $\mathrm{X}=2^{-\Delta \Delta \mathrm{Ct}}$, where $\Delta \Delta \mathrm{Ct}=\left(\mathrm{Ct}_{\text {target gene }}-\mathrm{Ct}_{\beta-\mathrm{Actin}}\right)$ sample $-\left(\mathrm{Ct}_{\text {target gene }}-\mathrm{Ct}_{\beta-\mathrm{Actin}}\right)$ control

\section{Reverse transcription PCR}

PCR was conducted using the DreamTaq Green PCR Master Mix according to the manufacturer`s instructions (K1082, Thermoscientific, Bremen, Germany). PCR products were loaded onto an agarose gel and separated by electrophoresis. The relative semi-quantitative optical density ratio of images was calculated using NIH Image J software, with $\beta$-Actin as an internal control.

\section{Protein extraction and Western blotting analysis}

After treatment, adipocytes were harvested and lysed in RIPA buffer containing $1 \mathrm{mM}$ phenylmethylsulfonyl fluoride (PMSF). Equal amounts of protein were electrophoresed on 10\% sodium dodecyl sulfate polyacrylamide gel (SDS-PAGE), and the bands were transferred to polyvinylidene fluoride membrane (Millipore, USA). The membrane was blocked and incubated with the relevant primary antibodies and then incubated with peroxidase-conjugated secondary antibodies (ZhongShanjinQiao, China). Chemiluminescence signals were detected and analyzed with BIO-RAD ChemiDoc MP Imaging System and Image Lab Software. Relative protein levels in each sample were normalized to $\alpha$-Tubulin to standardize the loading variations.

\section{Enzyme-linked immunosorbent assay (ELISA) for adiponectin}

During the process of F442A adipogenesis either with GH intervention or non-GH intervention, the culture mediums were collected and centrifuged $(12,000 \mathrm{rpm})$ for $10 \mathrm{~min}$ to remove debris. The supernatants were collected for adiponectin measurements using enzyme-linked immunosorbent assay (Elisa) Kits (cusabio, Wuhan, China) according to the manufacturer`s instructions. In brief, standards and samples were pipetted into a 96-well microplate which has been pre-coated with adiponectin antibody. After removing any unbound substances, a biotin-conjugated antibody specific for adiponectin was added to the wells. After washing, avidin conjugated horseradish peroxidase (HRP) was added to the wells. Following a wash to remove an unbound avidin-enzyme reagent, tetramethylbenzidine (TMB) substrate was incubated protect from light in each well and was stopped with $\mathrm{H}_{2} \mathrm{SO}_{4}$ stop solution. The optical density was measured with a microplate reader (iMark, Bio-Rad, USA) at $450 \mathrm{~nm}$. Relative adiponectin protein levels were normalized to standards.

\section{Statistical analysis}

All data are presented as mean \pm SEM from at least three independent experiments. Relative expression of genes, which was described as the fixed factor in our in vivo and in vitro experiments, is presented as GH-group/Control group. And the each differentiation time point is defined as the random factor. For comparison of quantitative data of two groups, Student's t-test was used, and for multiple comparisons above control due to GH at each time point, one-way ANOVA was used (SPSS17.0 software). P $<0.05$ was considered statistically significant.

\section{Results}

GH modulates the expression of genes related to adipocyte maturation and lipid Synthesis during adipogenesis

During the process of adipogenesis in 3T3-F442A pre-adipocytes, we examined the expression of two adipogenesis regulators $(C / E B P \alpha$ and $P P A R \gamma)$ (Fig. 1A and 1B) and two lipid synthesis related genes (FAS, FABP) (Fig. 1C and 1D), and found that the mRNA expression of $C / E B P \alpha, P P A R \gamma, F A S$ and $F A B P$ reached their peaks on day 6 in pre-adipocytes without GH treatment (Fig. 1A-1D). While the mRNA levels of FAS and FABP were reduced in 3T3-F442A pre-adipocytes treated with GH in different time points (from day 1 to day 12) 


\section{Cellular Physiology Cell Physiol Biochem 2016;39:2135-2148

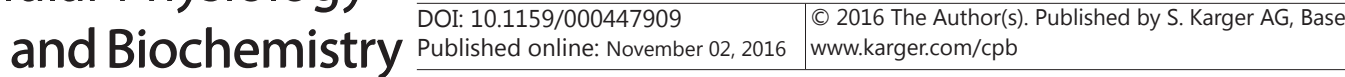 \\ Zhang et al.: GH on Lipid Maturation in Adipocytes}

Fig. 1. The effect of $\mathrm{GH}$ on the expression of a di p o c y te maturation or lipid accumulation related genes during adipogenesis of 3T3-F442A pre-adipocyte. The mRNA levels of several genes were quantitatively analyzed at different stages during 3 T 3 - F $442 \mathrm{~A}$ pre-adipocytes adipogenesis. (A) C/EBP $\alpha$; (B) PPARY; (C) FAS; (D) FABP. Results are shown as mean \pm SEM of three independent experiments. ${ }^{*} \mathrm{P}<0.05,{ }^{* *} \mathrm{P}<0.01, \mathrm{GH}$-treated cells vs. non-GH-treated control cells (NC) at the same time point during the process of adipogenesis.

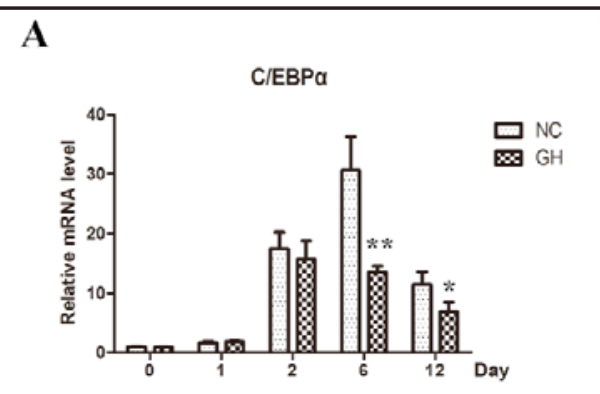

C
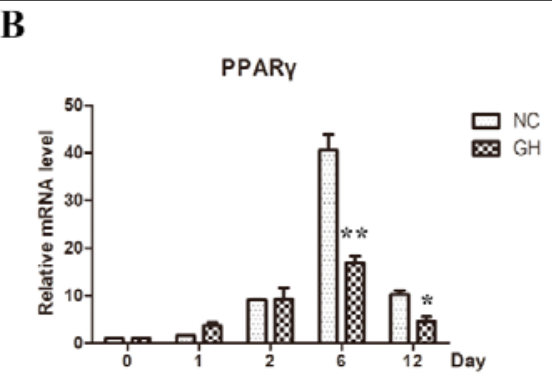

D
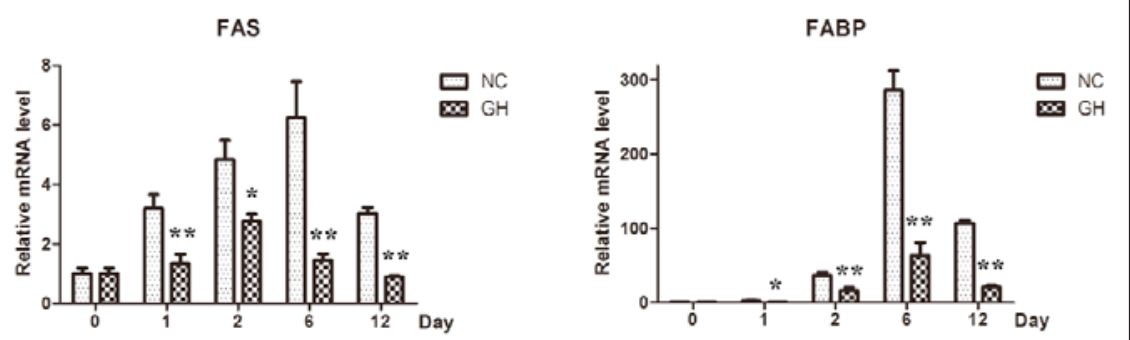

Fig. 2. The effect of $\mathrm{GH}$ on the expression of lipid-lysis or lipid-consuming proteins during adipogenesis of 3 T 3 - F 442 A pre-adipocyte. The mRNA levels of several molecules were quantitatively analyzed at different stages during 3T3L1 pre-adi-

\section{A}

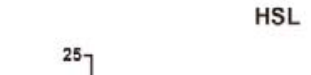

B

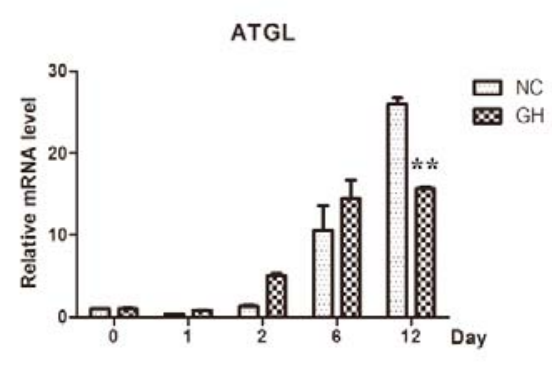

pocytes differentiation. (A) HSL; (B) ATGL; (C) UCP1. Results are shown as mean \pm SEM of three independent experiments. ${ }^{*} \mathrm{P}<0.05,{ }^{* *} \mathrm{P}<0.01$, GH-treated cells vs. non-GH-treated control cells $(\mathrm{NC})$ at the same time point during the process of adipogenesis.

(Fig. 1C and 1D) and the mRNA expression of $C / E B P \alpha$ and PPAR $\gamma$ were dramatically inhibited 6 days after differentiation (Fig. 1A and 1B).

GH modulates the expression of genes related to lipolysis during adipogenesis

During adipogenesis of 3T3-F442A pre-adipocytes, GH markedly enhanced mRNA expressions of $H S L$ and ATGL at later time points (Fig. 2A and 2B), and mRNA level of UCP1 were significantly increased in every different time points (Fig. 2C). 


\section{Cellular Physiology Cell Physiol Biochem 2016;39:2135-2148 \begin{tabular}{ll|l} 
DOI: 10.1159/000447909 & $\begin{array}{l}\text { O 2016 The Author(s). Published by S. Karger AG, Basel } \\
\text { and Biochemistry }\end{array}$ \\
\cline { 2 - 3 } & Published online: November 02, 2016 & www.karger.com/cpb \\
\hline
\end{tabular} \\ Zhang et al.: GH on Lipid Maturation in Adipocytes}

Fig. 3. Western blotting or ELISA analyses the GH impact on protein expression of adipocyte differentiation related genes during the adipogenesis of 3T3F442A pre-adipocytes. (A) $\mathrm{C} / \mathrm{EBP} \alpha$, PPAR $\gamma$, FAS and $\alpha$-Tubulin were western blotted with specific antibodies. (B) Secretion of adiponectin was analysults are shown as mean \pm SEM of three independent experiments. $\quad * \mathrm{P}<0.05$, ${ }^{* *} \mathrm{P}<0.01, \mathrm{GH}$-treated cells vs. non-GH-treated control cells (NC) at the same time point during the process of adipogenesis. zed with ELISA assay. Re-

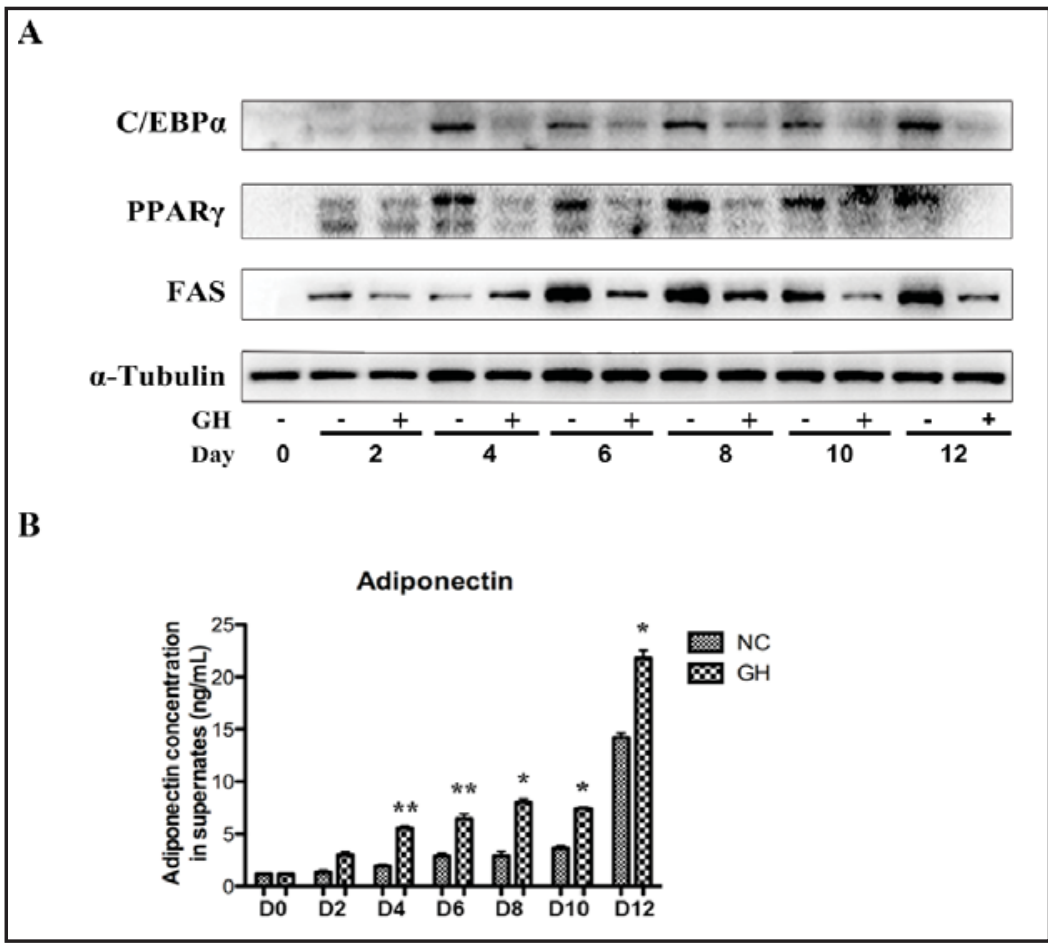

GH has the effect on protein expression of C/EBP $\alpha$, PPAR $\gamma$, FAS and adiponectin

As shown in Fig. 3A, GH strongly inhibited the protein expression of C/EBP $\alpha$, PPAR $\gamma$ and FAS from day 6 till day 12 during adipogenesis of F442A pre-adipocytes. To determine the role of $\mathrm{GH}$ in regulation of adiponectin secretion during the maturation of lipids, the supernatant of cell culture medium were studied. As shown in Fig. 3B, GH significantly increased secretion of adiponectin from day 4. The coefficient variation (CV) of intra-assay was less than $6.5 \%$, and the $\mathrm{CV}$ of inter-assay was less than $8 \%$. The data presented in Fig. 3B were inter-assay values analyzed from the means of three parallel intra assays.

GH regulates the expression of genes associated with lipid metabolism in mature 3T3F442A adipocytes

cDNA microarray analysis showed the gene expression profile (Fig. 4A). 99 genes were showed differential expression (Table 2), 23 genes were showed significantly altered with fold-change values $\geq 2$ or $\leq 0.5$ in GH-treated mature 3T3-F442A adipocytes compared with control cells. Of the 23 genes, 14 were up-regulated and 9 down-regulated (Table 3 ). The data of this array have been deposited in NCBI's Gene Expression Omnibus and are accessible through GEO Series accession number GSE86830.

The Gene Ontology (GO) categories showed that 18 genes are associated with lipid metabolism (Table 4). GH inhibited the expression of several genes in fatty acid biosynthesis and elongation pathway at $24 \mathrm{~h}$ (Fig. 5).

These results were further confirmed by reverse transcript-PCR (Fig. 4B) and real time RT-PCR for genes, Adipor2 and SOCS2 (Fig. 4C and 4D). After the differentiated 3T3-F442A adipocytes were treated with $\mathrm{GH}(125 \mathrm{ng} / \mathrm{mL})$ for $24 \mathrm{~h}$, the mRNA expression of Adipor2 was increased by 3-5 folds and the mRNA level of SOCS2 was increased by 28 -folds compared to non-GH treatment control cells.

GH modulates the expression of genes related to lipolysis in differentiated 3T3-F442A adipocytes

Compared with control cells (treated with PBS), GH treatment for $24 \mathrm{~h}$ significantly increased the mRNA levels of adiponectin and UCP1, (Fig. 6C and 6E), while the expressions of $H S L$ and leptin were not influenced by GH treatment (Fig. 6A and 6D). 


\section{Cellular Physiology Cell Physiol Biochem 2016;39:2135-2148 \begin{tabular}{ll|l} 
DOI: 10.1159/000447909 & $\begin{array}{l}\text { C } 2016 \text { The Author(s). Published by S. Karger AG, Basel } \\
\text { www.karger.com/cpb }\end{array}$ \\
\hline
\end{tabular}}

Fig. 4. Determination of sion of SOCS2 and Adipor2 in 3T3-F442A adipocytes with cDNA microarray, reverse transcription PCR or real-time quantitative PCR (qPCR). (A) Microarray analysis exhibited the expression profile of genes modulated by GH. (B) Reverse transcription PCR showed that GH-induced mRNA expression of Adipor2 and SOCS2. (C,D) GH-induced the expression of Adipor 2 and SOCS2 were detected and confirmed with qPCR. Results are shown as mean \pm SEM of three independent experiments. ${ }^{*} \mathrm{P}<0.05,{ }^{* *} \mathrm{P}<0.01, \mathrm{GH}$-treated cells vs. non-GH-treated control cells (NC). GH-induced mRNA expres-

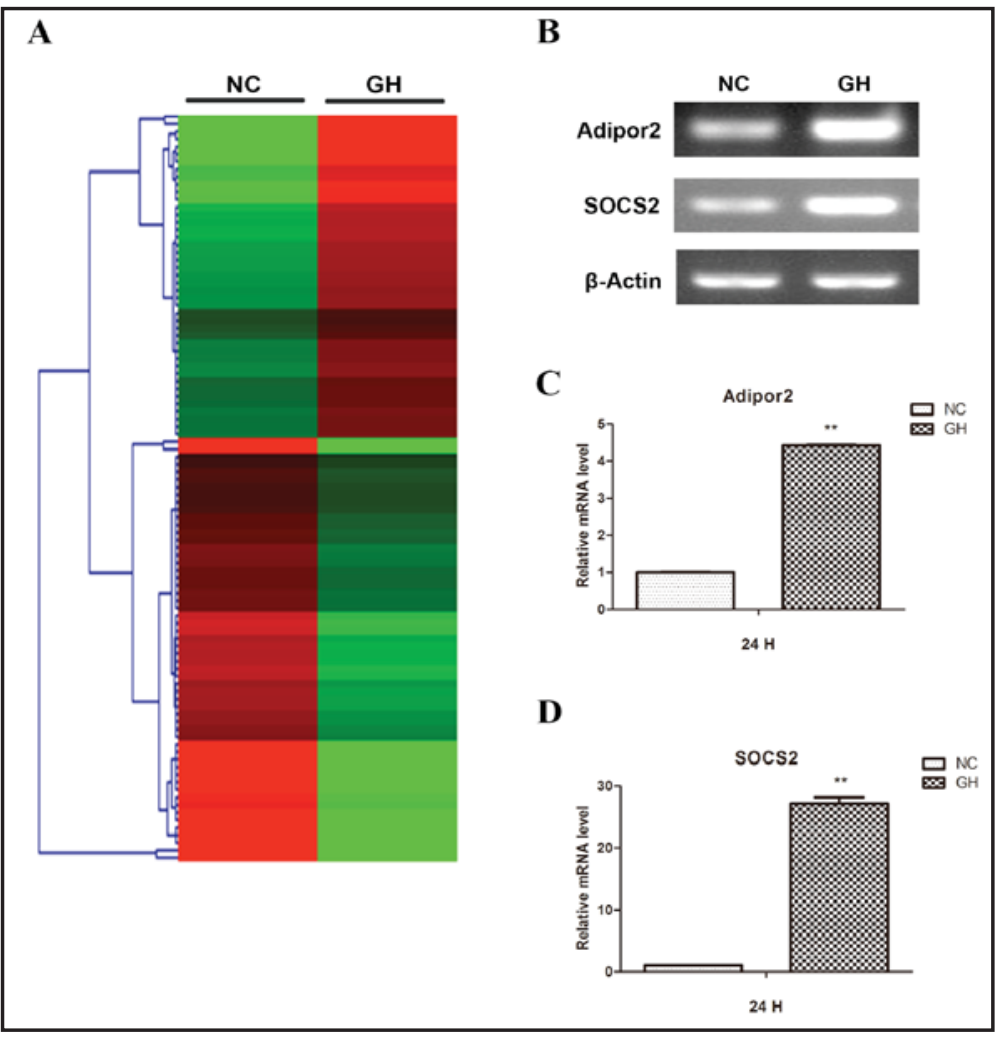

GH modulates the expression of genes related to lipolysis in primary adipocytes from obese C57/BL6 mice

12 weeks of high-fat diet induced markedly increased in body weight of C57/BL6 mice. As shown in Fig. 7A, compared with control obese mice, GH significantly decreased the mRNA expression of PPAR , FAS and FABP in primary adipocytes. While the mRNA level of HSL, ATGL, UCP1 and Adipor2 were increased strongly in GH-treated mice (Fig. 7B).

\section{Discussion}

In the present study, we investigated the effects of GH on expression of genes related to lipid accumulation or degradation in 3T3-F442A pre-adipocytes during differentiation, as well as the effect of GH on expression of genes related to adipocyte maturation in 3T3-F442A adipocytes and in obese C57/BL6 mice.

The process of pre-adipocyte differentiation into adipocyte is called adipogenesis. The majorfeatures of differentiatedadipocytes include morphological change, growtharrest, highly expression of lipogenic genes and production of hormones like leptin. And some adipokines such as leptin and TNF- $\alpha$ may limit the degree of maturation of preadipocytes [12]. $C / E B P \alpha$ and PPAR $\gamma$ are two important markers or lipogenic genes for pre-adipocyte transformation into adipocyte, and for adipogenic diferentiation from multipotent mesenchymal stem cells to mature adipocytes [15]. After this critical transformation, the adipocyte will accumulate more triglyceride, which is called maturation. Therefore, adipogenesis includes two stages, one is initiation and transformation, the other is maturation.

It was reported that $\mathrm{GH}$ induced $\mathrm{C} / \mathrm{EBP} \beta$ expression may be involved the initiation of the adipocyte differentiation program [16]. Nixon reported that GH presented in serum promoted the conversion 3T3 cells into adipose cells [7]. Kawai reported that GH induced STAT5 pathway stimulated adipogenesis of 3T3-L1 cells in cooperation with C/EBP $\beta$ and PPAR 2 2 [17]. But GH stimulated lipolysis has also been documented in animal study [14]. Mc Waters reported transgenic mice with abolished STAT5B activation resulted in obesity [18], 

Cellular Physiology Cell Physiol Biochem 2016;39:2135-2148

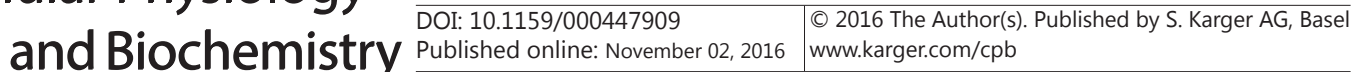

Zhang et al.: GH on Lipid Maturation in Adipocytes

Table 2. 99 differentially expressed genes of Microarray analysis in 3T3-F442A adipocytes treated with GH for $24 \mathrm{H}$

\begin{tabular}{|c|c|c|c|c|}
\hline & Gene Symbol & Ratio & Name & $\begin{array}{l}\text { Genebank- } \\
\text { accession id }\end{array}$ \\
\hline 1 & Adipor2 & 5.467 & adiponectin receptor 2 & AY724514 \\
\hline 2 & Socs2 & 4.0799 & $\begin{array}{l}\text { suppressor of cytokine signaling } 2 \\
\text { insulin-like growth factor-binding protein }\end{array}$ & AF075382 \\
\hline 3 & lgfals & 3.5557 & $\begin{array}{l}\text { complex acid labile chain precursor } \\
\text { FXYD domain-containing ion transport }\end{array}$ & BF556234 \\
\hline 4 & Fxyd5 & 2.7465 & $\begin{array}{l}\text { regulator } 5 \text { precursor: } \\
\text { GAAGGGGACCTTGGTCTGTGCCAACCCCAGTGATC }\end{array}$ & BC060571 \\
\hline 5 & - & 2.6724 & TGAGAGTTCAGAAGTGCATTAAAAGATTGGAGCAA & XM_573163 \\
\hline 6 & Raly & 2.4987 & $\begin{array}{l}\text { hnRNP-associated with lethal yellow (predicted) } \\
\text { TGACACTTCTCTGACCAGAGATCCTCTGGTCATAG }\end{array}$ & XM_575273 \\
\hline 7 & - & 2.3549 & AACTTGGCCAAAAGCAGGTGATCCCAGGTATGTGA & XM_573163 \\
\hline 8 & Pdlim1 & 2.3445 & PDZ and LIM domain protein 1 & BC072465 \\
\hline 9 & Ppp2r5a & 2.2872 & similar to protein phosphatase 2 & XM_232413 \\
\hline 10 & Capn6 & 2.2389 & calpain- 6 & AF067793 \\
\hline 11 & $\mathrm{Clec} 3 \mathrm{~b}$ & 2.216 & similar to tetranectin & XM_236746 \\
\hline 12 & Dpt & 2.2075 & similar to early quiescence protein-1 & XM_213925 \\
\hline 13 & Obfc2a & 2.1981 & Rn30014131 & BC089852 \\
\hline 14 & $A p 2 b 1$ & 2.0603 & adapter-related protein complex 2 beta 1 subunit & M77246 \\
\hline 15 & Tmed 9 & 1.9552 & similar to gp $25 \mathrm{~L} 2$ protein & BC088422 \\
\hline 16 & Ghr & 1.94805 & growth hormone receptor precursor & j04811 \\
\hline 17 & Prps1 & 1.8102 & ribose-phosphate pyrophosphokinase I & BC088149 \\
\hline 18 & Cald1 & 1.8041 & $\begin{array}{l}\text { non-muscle caldesmon } \\
\text { CMP-N-acetylneuraminate-beta-galactosamide- }\end{array}$ & NM_013146 \\
\hline 19 & St3gal4 & 1.7849 & alpha-2,3-sialyltransferase (EC 2.4.99.-) & NM_203337 \\
\hline 20 & Pten & 1.7688 & phosphatase and tensin & AF017185 \\
\hline 21 & Shisa4 & 1.7097 & similar to RIKEN cDNA 9330132005 & XM_341125 \\
\hline 22 & Gadd $45 \mathrm{~g}$ & 1.664 & Growth arrest and DNA-damage-inducible protein GADD45 gamma & XM_237999 \\
\hline 23 & Acadsb & 1.6603 & $\begin{array}{l}\text { Acyl-CoA dehydrogenase } \\
\text { ATGTGAAGAAGGTAAAATTGGTCATTCATCTGTGG }\end{array}$ & U64451 \\
\hline 24 & . & 1.6561 & GTGTGCCGCTGAACCATCCAGTAGGACACAAACCT & XM_234847 \\
\hline 25 & RGD1563150 & 1.6366 & similar to B-cell translocation gene 1 & XM_233323 \\
\hline 26 & Ppa1 & 1.6277 & Pp protein (Fragment) & BC099794 \\
\hline 27 & Aacs & 1.627 & acetoacetyl-CoA synthetase & BC061803 \\
\hline 28 & Rasl11a & 1.6191 & Ras-like family 11 member A & CV111965 \\
\hline 29 & Lrrc17 & 1.5988 & leucine rich repeat containing 17 & BC079098 \\
\hline 30 & Amy1 & 1.5972 & amylase 1 , salivary & AB057450 \\
\hline 31 & Taf15 & 1.5952 & similar to TAF15 RNA polymerase II & XP_237792 \\
\hline 32 & Ifi35 & 1.5599 & interferon-induced protein 35 & BC088222 \\
\hline 33 & Rap2b & 1.5591 & Ras-related protein Rap-2b & DV216028 \\
\hline 34 & Rraga & 1.5453 & $\begin{array}{l}\text { Ras-related GTP-binding protein ragA } \\
\text { CCTACATTACTCTGATGAAGATGTCACCAAATACAATGACCTCATCCCGGCA }\end{array}$ & BC061850 \\
\hline 35 & - & 1.5306 & GAGAGCAGCAGCCTGACA & XM_340930 \\
\hline 36 & Dhxy & 1.5302 & similar to RNA helicase A & XM_239780 \\
\hline 37 & St3gal1 & 1.5226 & sialyltransferase $4 \mathrm{~A}$ & A) 748840 \\
\hline 38 & Hagh & 1.5197 & hydroxyacylglutathione hydrolase & ВС097301 \\
\hline 39 & Fam $38 a$ & 1.518 & similar to Protein FAM $38 \mathrm{~A}$ & XM_341708 \\
\hline 40 & Gpc4 & 1.5174 & Rn30002180 & ВC081962 \\
\hline 41 & Syngr1 & 1.5082 & $\begin{array}{l}\text { synaptogyrin-1 (p29) } \\
\text { GATGTCTCGGGCCAAGCATCATGCCATCTCTGCTA }\end{array}$ & U39549 \\
\hline 42 & . & 1.5045 & AACTGAACAAGCCCTTCCTGTTTGATACCAAGCCT & NM_172008 \\
\hline 43 & Prkrip1 & 1.5028 & similar to PRKR interacting protein 1 & XM_573387 \\
\hline & & & CTACCTCTGGAAAAGATTCTTCACAAAGGCGGTGA & \\
\hline 44 & - & 0.6649 & GTCCCTGTGTTGGTATGTTTGGGGCAGTGGTGCTG & Rn30022029 \\
\hline 45 & Kitl & 0.6646 & $\begin{array}{l}\text { kit ligand precursor } \\
\text { CAGCTGCTTAAATCTGCTGGATCGCTGTGATCAGC }\end{array}$ & NM_021843 \\
\hline 46 & - & 0.6636 & CCCTGGCATTGTTAAAAGATATCAGAAGTGTCTTG & XM_243815 \\
\hline 47 & Stat3 & 0.6635 & $\begin{array}{l}\text { signal transducer and activator of transcription } 3 \\
\text { CTGTAGGTGCAGTGTGCTGCAGGGT }\end{array}$ & NM_012747 \\
\hline 48 & - & 0.6618 & $\begin{array}{l}\text { GGATCATTCACAGAATCAAAAGAGA } \\
\text { CCCTGGAATGACTATGTCAGCACAGAGCCCCACAA }\end{array}$ & XM_213624 \\
\hline 49 & - $\quad$ & 0.6614 & TGTTAAATTCTGTAGATCCCAATGTTGGCGGACAG & XM_230449 \\
\hline 50 & rOCNC2 & 0.6576 & $\begin{array}{l}\text { cyclic-nucleotide-gated olfactory channel OCNC2 } 2 \text { subunit. } \\
\text { AGCTGCACCCCGTCACATGATGCGTCTGGACATCC }\end{array}$ & U12623 \\
\hline 51 & - & 0.655 & $\begin{array}{l}\text { GTTCCCTGCTACAAGATGCTGCAATTGAAGAAGTA } \\
\text { CCAGTTGACCTCGTCTCCCACGTGCATCGTGAGAC }\end{array}$ & XM_234416 \\
\hline 52 & - & 0.6524 & CTTGTAGGTTTCCGAACATTTTCCCATTGATAGCT & Rn30026823 \\
\hline 53 & Porcn & 0.6507 & similar to porcupine-D & XM_228781 \\
\hline 54 & RGD1309676 & 0.6494 & $\operatorname{Rn} 30010267$ & ВC079275 \\
\hline 55 & Cdc27 & 0.6464 & cell division cycle 27 homolog & BC097475 \\
\hline 56 & Angpt/4 & 0.6449 & angiopoietin-related protein 4 precursor & NM_199115 \\
\hline 57 & Gnao1 & 0.6441 & guanine nucleotide-binding protein $\mathrm{G}(\mathrm{o})$ & M17526 \\
\hline 58 & Csgalnact1 & 0.643 & similar to chondroitin beta1,4 $\mathrm{N}$-acetylgalactosaminyltransferase & XM_224757 \\
\hline 59 & Arsj & 0.6427 & arylsulfatase J & XM 227873 \\
\hline
\end{tabular}

while STAT5B activation needs GH and GHR association. It seems that the role of growth hormone in adipocyte differentiation and lipolysis is still controversial. 


\section{Cellular Physiology Cell Physiol Biochem 2016;39:2135-2148 \begin{tabular}{ll|l} 
and Biochemistry $10.1159 / 000447909$ & $\begin{array}{l}\text { C 2016 The Author(s). Published by S. Karger AG, Basel } \\
\text { www.karger.com/cpb }\end{array}$ \\
\hline
\end{tabular} \\ Zhang et al.: GH on Lipid Maturation in Adipocytes}

\begin{tabular}{|c|c|c|c|c|}
\hline & Gene Symbol & Ratio & Name & $\begin{array}{l}\text { Genebank- } \\
\text { accession id }\end{array}$ \\
\hline 60 & Lrp1 & 0.6416 & Irp1_predicted protein & XM_243524 \\
\hline 61 & Serping1 & 0.6404 & serine (or cysteine) proteinase inhibitor & ВC061860 \\
\hline 62 & Phf17 & 0.6404 & similar to mKIAA1807 protein & XM_227074 \\
\hline 63 & Lxn & 0.6378 & latexin & BC081763 \\
\hline 64 & Slpi & 0.6334 & secretory leukocyte peptidase inhibitor & CB567769 \\
\hline 65 & Pms1 & 0.6332 & Rn30003624 & BC061722 \\
\hline 66 & Spp1 & 0.633 & $\begin{array}{l}\text { osteopontin precursor (Bone sialoprotein-1) } \\
\text { TCGCTCAAGGGATAGACGAACCAATCGTTCCAGTC }\end{array}$ & $\mathrm{BC} 078874$ \\
\hline 67 & $\cdot$ & 0.6309 & $\begin{array}{l}\text { GCAGTAGAAGTCGAGATAGGCGTAAAATTGAGGAT } \\
\text { AGGACCAATTTATGACCAAACTTATGCTGGTGGAC }\end{array}$ & BC091301 \\
\hline 68 & - & 0.6309 & $\begin{array}{l}\text { GGCTGGGTCTGTTTGTCTTCTCCCAAGAAATGGTC } \\
\text { TTTCCAGCCTGAAGCCAGCCCATCTCACCTGACAC }\end{array}$ & XM_214778 \\
\hline 69 & - & 0.6285 & $\begin{array}{l}\text { TGAACAGCGGCTTGGTAGAAAGTGAAGACCTGTGA } \\
\text { GTGCCACAGATGGATCCTGCTCCTG }\end{array}$ & XM_214338 \\
\hline 70 & - & 0.6258 & CGCTGGCTCCTGCAAATGCAAACAA & CB313235 \\
\hline 71 & Mmp10 & 0.625 & $\begin{array}{l}\text { stromelysin-1 precursor } \\
\text { AGAGGGTATTCAGAGATTAATAGGACACGGAGCAG }\end{array}$ & XM65253 \\
\hline 72 & - $\quad$ & 0.6224 & AGGACTCAAGAGCTGACCAGTTTGCCAACAAGTGG & AY325259 \\
\hline 73 & RGD1564579 & 0.6203 & similar to yippee-like 3 & XM_215057 \\
\hline 74 & RGD1308470 & 0.6187 & $\mathrm{Rn} 30004203$ & $\mathrm{BC} 087681$ \\
\hline 75 & Abhd12 & 0.6152 & $\begin{array}{l}\text { Rn30025950 } \\
\text { TCCCACCACTGAGCTCCACCCTCCC }\end{array}$ & XM_230778 \\
\hline 76 & - $\quad$ & 0.6142 & CGAACTGAACCTAGTCTTTGAACCA & Rn30012591 \\
\hline 77 & Adamts5 & 0.5943 & a disintegrin-like and metalloprotease (reprolysin type) & AY382879 \\
\hline 78 & Edn1 & 0.5935 & $\begin{array}{l}\text { endothelin-1 precursor (ET-1) } \\
\text { CCTGTATAGTCCTGCGCATGTTCCCCACACAGAA }\end{array}$ & M64711 \\
\hline 79 & - & 0.5918 & СССАCTGTATTTACCTGTTCTACTTGTCACCTTTCA & CB713932 \\
\hline 80 & Fgf7 & 0.5915 & keratinocyte growth factor precursor (KGF) & BG662860 \\
\hline 81 & $E m b$ & 0.5812 & embigin precursor & BC061846 \\
\hline 82 & Macrod1 & 0.5689 & protein LRP16 (Fragment) & AF404762 \\
\hline 83 & Casp4 & 0.5686 & $\begin{array}{l}\text { caspase } 11 \\
\text { GTGAGTTTCTCATCTAAGCCTAGCGTTTGAACCT }\end{array}$ & BC089095 \\
\hline 84 & . & 0.5593 & GCCAGGCCCACAACCTAAATGCAGATTCAAACCCA & NM 022671 \\
\hline 85 & Galnt2 & 0.5588 & $\begin{array}{l}\text { similar to UDP-N-acetyl-alpha-D-galactosamine } \\
\text { TGACCTGCTGGACTGCCTGGTACACGTATCCTACC }\end{array}$ & XM_238057 \\
\hline 86 & . & 0.5464 & TGGAACTGTACAAGGAAGAGTTCCGAGATCTGCTC & XM_218828 \\
\hline 87 & Zcchc11 & 0.537 & $\begin{array}{l}\text { similar to hypothetical protein } \\
\text { CCTGAAGAGCTTCAAAAACAACCTGGTGGACATCA }\end{array}$ & XM_233345 \\
\hline 88 & - & 0.5354 & TTCAGCAGAACAAGGAGAGGTGGAAAGAGTTGGCT & AF327838 \\
\hline 89 & Mmp3 & 0.532833333 & Stromelysin-1 precursor & X02601 \\
\hline 90 & Fam $3 \mathrm{c}$ & 0.5306 & $\begin{array}{l}\text { FAM3C-like protein } \\
\text { ACCCACACACTTCAGTCAGCAGAACTCCTCAAAAG }\end{array}$ & AY228475 \\
\hline 91 & . & 0.4929 & TTTCTAGCCAGCCAAAGGCCAAAGAAGAATCTCCT & XM 216295 \\
\hline 92 & Lipa & 0.4892 & $\begin{array}{l}\text { lysosomal acid lipase } \\
\text { GGGAAACAGCAGAGGAAGTACCTGGGCAAAGAAAC }\end{array}$ & NM_012732 \\
\hline 93 & . & 0.4861 & ATGTGACCCTAAGCCCAGATTCTGAAGAATTCTGG & XM_220070 \\
\hline 94 & Lcn2 & 0.4443 & neutrophil gelatinase-associated lipocalin & BC089053 \\
\hline 95 & Grem1 & 0.4381 & gremlin-1 precursor & Y10019 \\
\hline 96 & Wwtr1 & 0.3517 & Rn30015203 & BC097968 \\
\hline 97 & Hmox1 & 0.3478 & heme oxygenase 1 & NM_012580 \\
\hline 98 & Nid1 & 0.3442 & nidogen (Entactin) & XM_213954 \\
\hline 99 & $\mathrm{Hp}$ & 0.2672 & haptoglobin precursor & AF476963 \\
\hline
\end{tabular}

It has been reported that the mRNA expression of 22 genes associated with lipid metabolism was modulated in 3T3-F442A adipocytes in response to $\mathrm{GH}$ for $48 \mathrm{~h}$ by exploiting microarray analysis [19]. Our microarray data showed that the mRNA expression of 18 genes associated with lipid metabolism changed in mature 3T3-F442A adipocytes upon GH treatment for $24 \mathrm{~h}$. Among these 18 genes, Adipor2 and Fads1 were up-regulated, and genes such as $S c d 2, L t c 4 s, A c o x 1$ and $S c d 1$ were down-regulated by GH. These genes are overlapped with the published data and the trend of these genes' expression in response to GH is in concert with the published data [19]. It is also concluded by Jessica Schwartz's group that prolonged GH treatment inhibits genes associated with lipid and cholesterol biosynthesis [19]; in their report, some genes involves in fatty acid synthesis or cholesterol synthesis pathway were reduced in mRNA expression in 3T3-F442A adipocytes upon GH treatment for $48 \mathrm{~h}$ [19]. As well as in the published article, our microarray data showed GH down-regulates $S c d 1$ and $S c d 2$, which are closely related to unsaturated fatty acid (oleic acid) biosynthesis. Our microarray data also exhibited that GH increased the expression of acyl-CoA dehydrogenase (Acadsb) which involved in the pathway for fatty acid $\beta$-oxidation; though the increased fold is not so big, potentially GH has the impact on fatty acid clearance. Besides, our microarray data also showed that GH down-regulated Fabp4, which is essential 


\section{Cellular Physiology Cell Physiol Biochem 2016;39:2135-2148 \begin{tabular}{ll|l} 
& DOI: 10.1159/000447909 & $\begin{array}{l}\text { @ 2016 The Author(s). Published by S. Karger AG, Basel } \\
\text { www.karger.com/cpb }\end{array}$ \\
\hline
\end{tabular} \\ Zhang et al.: GH on Lipid Maturation in Adipocytes} analysis of modulated adipocytes treated with GH for $24 \mathrm{H}$ (fold-change values $\geq 2$ or $\leq 0.5$ )
Table 3. Microarray genes in 3T3-F442A

\begin{tabular}{|c|c|c|c|}
\hline Name & Ratio & Oligo id & $\begin{array}{l}\text { Genebank- } \\
\text { accession id }\end{array}$ \\
\hline Adipor2 & 5.467 & Rn30007263 & AY724514 \\
\hline SOCS2 & 4.0799 & R002975_01 & AF075382 \\
\hline lgfals & 3.5557 & Rn30013818 & BF556234 \\
\hline Fxyd5 & 2.7465 & Rn30019436 & BC060571 \\
\hline- & 2.6724 & $\begin{array}{l}\text { GAAGGGGACCTTGGTCTGTGCCAACCCCAGTGATCTGAGAGTTCAG } \\
\text { AAGTGCATTAAAAGATTGGAGCAA }\end{array}$ & \\
\hline Raly & 2.4987 & Rn30016005 & XM_575273 \\
\hline 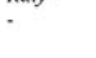 & 2.3549 & $\begin{array}{l}\text { TGACACTTCTCTGACCAGAGATCCTCTGGTCATAGAACTTGGCCAA } \\
\text { AAGCAGGTGATCCCAGGTATGTGA }\end{array}$ & \\
\hline Pdlim1 & 2.3445 & R002183_01 & BC072465 \\
\hline Ppp2r5a & 2.2872 & Rn30000051 & XM_232413 \\
\hline Capn6 & 2.2389 & R000399_01 & AF067793 \\
\hline Clec $3 b$ & 2.216 & Rn30004060 & XM_236746 \\
\hline Dpt & 2.2075 & Rn30002616 & XM_213925 \\
\hline obfc $2 a$ & 2.1981 & Rn30014131 & ВС089852 \\
\hline$A p 2 b 1$ & 2.0603 & R004098_01 & M77246 \\
\hline - & 0.4928 & $\begin{array}{l}\text { ACCCACACACTTCAGTCAGCAGAACTCCTCAAAAGTTTCTAGCCAGC } \\
\text { CAAAGGCCAAAGAAGAATCTCCT }\end{array}$ & \\
\hline Lipa & 0.4892 & $\begin{array}{l}\text { GGGAAACAGCAGAGGAAGTACCTGGGCAAAGAAACATGTGACCCTA } \\
\text { AGCCCAGATTCTGAAGAATTCTGG }\end{array}$ & NM_012732 \\
\hline - & 0.4861 & Rn30017550 & \\
\hline Len2 & 0.4443 & R002276_01 & BC089053 \\
\hline Grem1 & 0.4381 & $\operatorname{Rn} 30024343$ & Y10019 \\
\hline Wwtr1 & 0.3517 & Rn30015203 & ВС097968 \\
\hline Hmox1 & 0.3478 & R000442_01 & NM_012580 \\
\hline Nid1 & 0.3442 & Rn30002219 & XM_213954 \\
\hline Hр & 0.2672 & R002022_01 & AF476963 \\
\hline
\end{tabular}

Table 4. Genes associated with lipid metabolism change in mRNA expression in 3T3-F442A adipocytes upon GH treatment for $24 \mathrm{H}$

\begin{tabular}{llll}
\hline Gene Symbol & Ratio & Name & $\begin{array}{l}\text { Genebank- } \\
\text { accession id }\end{array}$ \\
\hline Adipor2 & 5.467 & adiponectin receptor 2 & AY724514 \\
SOCS2 & 4.0799 & suppressor of cytokine signaling 2 & AF075382 \\
Igfals & 3.5557 & insulin-like growth factor-binding protein & BF556234 \\
Acadsb & 1.6603 & acyl-Coenzyme A dehydrogenase & U64451 \\
Aacs & 1.627 & acetoacetyl-CoA synthetase & BC061803 \\
& & & \\
Fads3 & 0.8601 & fatty acid desaturase 3 & AJ494720 \\
Acaa2 & 0.8483 & acetyl-CoA acyltransferase 2 & X05341 \\
Gcdh & 0.8466 & glutaryl-CoA dehydrogenase & XM_344744 \\
Hadh & 0.8447 & 3-hydroxyacyl-CoA dehydrogenase & AF069770 \\
Ppap2a & 0.8406 & lipid phosphate phosphohydrolase 1 & CF110609 \\
Dhhadh & 0.8172 & enoyl-CoA hydratase & BC089777 \\
Scd2 & 0.8159 & stearoyl-CoA desaturase 2 & AB032243 \\
Ltc4s & 0.7619 & leukotriene C4 synthase & AB048790 \\
Acaca & 0.7579 & acetyl-CoA carboxylase 1 & J03808 \\
Fabp3 & 0.7434 & fatty acid binding protein 3 & CB698942 \\
Acox1 & 0.7388 & acyl-CoA oxidase 1, palmitoyl & J02752 \\
Fabp4 & 0.7005 & fatty acid binding protein 4 & BC074002 \\
Scd1 & 0.6699 & stearoyl-CoA desaturase 1 & J02585 \\
\hline
\end{tabular}

Fig. 5. Schematic presentation of the genes down-regulated by GH on lipid acid biosynthesis pathway at $24 \mathrm{~h}$ analyzed from microarray data. Each number stands for a specific gene which is listed on the right.

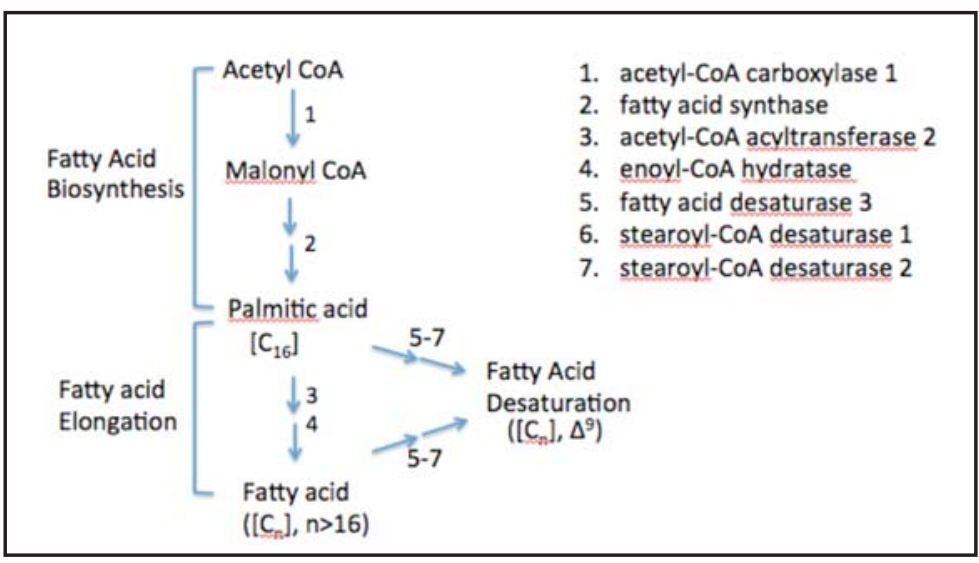

for fatty acid transporting into adipocytes; therefore, $\mathrm{GH}$ might reduce the triglycerol synthesis in adipocytes. In a word, our data confirmed the conclusion about the impact of GH on lipid metabolism in the published research article [19], though we chose a different GH 


\section{Cellular Physiology Cell Physiol Biochem 2016;39:2135-2148 \begin{tabular}{ll|l} 
and Biochemistry & $\begin{array}{l}\text { DOI: 10.1159/000447909 } \\
\text { Published online: November 02, } 2016\end{array}$ & $\begin{array}{l}\text { O 2016 The Author(s). Published by S. Karger AG, Basel } \\
\text { www.karger.com/cpb }\end{array}$ \\
\cline { 2 - 3 }
\end{tabular}

Fig. 6. Quantitative analyses the expression of lipolysis related genes at mRNA level in mature 3T3-F442A adipocytes treated with $\mathrm{GH}$. (A) HSL; (B) ATGL; (C) adiponectin; (D) leptin; (E) UCP1. Results are shown as mean \pm SEM experiments. $\quad * \mathrm{P}<0.05$, ** $\mathrm{P}<0.01, \quad \mathrm{GH}$-treated cells vs. non-GH-treated control cells (NC). of three independent

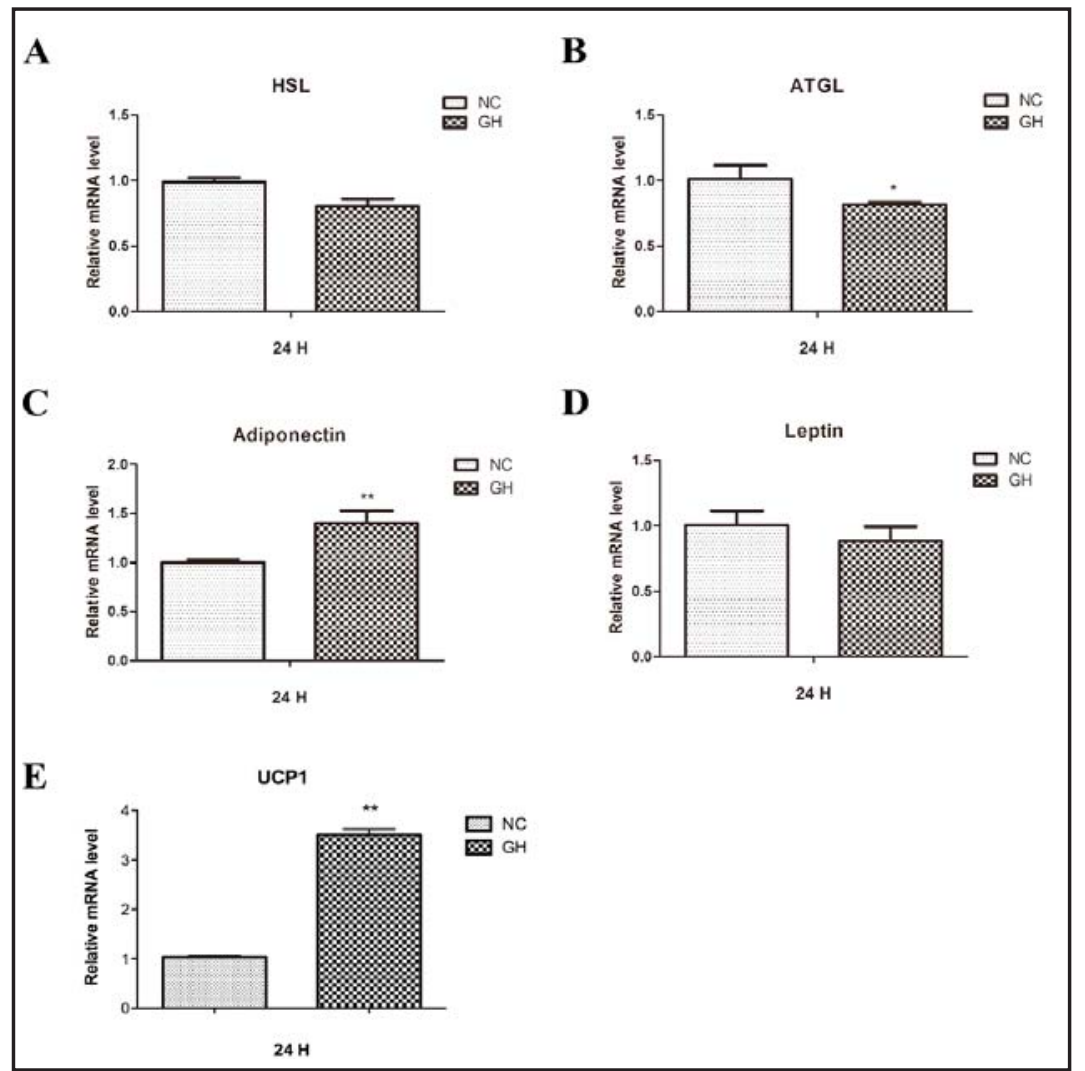

Fig. 7. Effect of GH on the expression of lipid or lipolysis related genes in vivo. Epididymal adipose tissues were separated from the high-fat diet induced-obese C57/BL6 mice. GH intervention mice were injected with $\mathrm{GH}(50 \mu \mathrm{g} / \mathrm{kg}$. BW), and control mice were injected with saline ( $n=6)$. (A) Quantitative analyses the expression of lipid accumulation related genes at mRNA level; (B) Lipolysis related genes at mRNA level. Results are shown as mean \pm SEM of three independent experiments. ${ }^{*} \mathrm{P}<0.05,{ }^{* *} \mathrm{P}<0.01$, GH group $(\mathrm{GH})$ vs. control (NC).

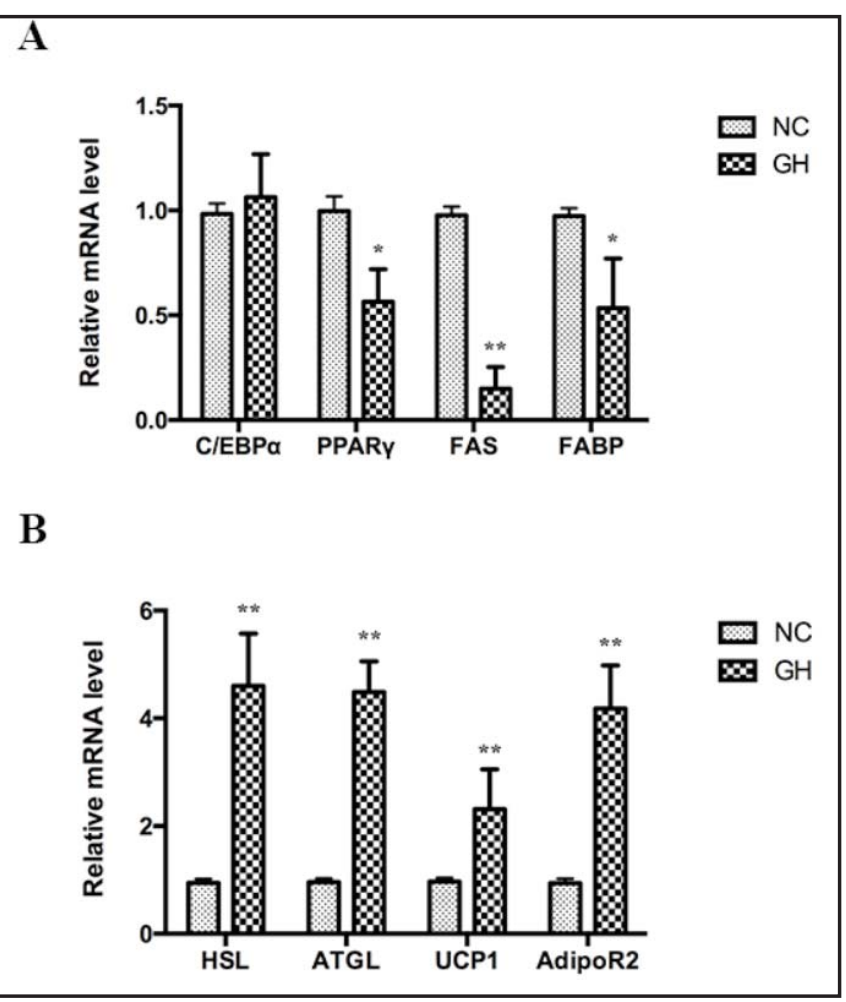

prolonged treatment time point ( $24 \mathrm{~h}$ ). Our microarray data also showed GH is able to reduce the expression of Angptl4 (angiopoietin-like protein 4, ratio 0.6449), Angpt1 (angiopoietin 1, ratio 0.5285 ) or Lipa (lysosomal acid lipase, ratio 0.4892 ) in 3T3-F442A adipocytes, the 


\section{Cellular Physiology Cell Physiol Biochem 2016;39:2135-2148 \\ \begin{tabular}{ll|l} 
and Biochemistry $10.1159 / 000447909$ & $\begin{array}{l}\text { O } 2016 \text { The Author(s). Published by S. Karger AG, Basel } \\
\text { www.karger.com/cpb }\end{array}$ \\
\hline
\end{tabular}}

Zhang et al.: GH on Lipid Maturation in Adipocytes

biological significance of which needs to be further studied.

It has been reported that SOCS2 overexpression significantly inhibited the expression of fatty acid synthase (FAS), the mRNA expression of adipose triglyceride lipase (ATGL), and the protein expression in swine primary adipocytes [20]. Besides, GH activated STAT5B, which in turn induces SOCS2 expression, finally SOCS2 inhibits insulin activation which is critical for adipogenesis and lipid accumulation. Our data clearly showed that GH in differentiated adipocytes increased the expression of SOCS2, indicating that GH potentially inhibits fatty acid synthesis and triglyceride synthesis in adipocytes.

Adiponectin is the most abundant peptide derived by adipose, play significant role in the etiology of obesity-related chronic diseases, such as insulin resistance and type 2 diabetes [21]. Adiponectin has been reported to reduce the expression of PPAR $\gamma$, FABP4, FAS, thereby reduce lipid content [22]. When adiponectin binds to its receptors (Adipor1/2), it activates adenosine 5 -monophosphate-activated protein kinase (AMPK), promoting glucose uptake by skeletal muscle via intracellular translocation of the glucose transpoter type 4 (GLUT4). Animal studies showed that Adipor1 transgene mice enabled mice to resist high fat/high sucrose diet-induced obesity while decreasing lipid accumulation [23]. We found that in mature F442A adipocytes, GH treatment increased the abundance or availability of adiponectin receptors, and increased adiponectin protein expression. Our animal study also confirmed that GH intervention increased the mRNA level of Adipor2 in epididymal adipose tissue from obese mice.

$\mathrm{C} / \mathrm{EBP} \alpha$ is the initial transcriptional factor induced by adipogenic hormone, and is thought to be required for PPAR $\gamma$ expression [24]. C/EBP $\alpha$ and PPAR $\gamma$ promoted differentiation by activating adipose-specific gene expression and by maintaining each other expression at high levels. In our adipogenesis system, C/EBP $\alpha$ and PPAR $\gamma$ protein expression levels reached their peaks at 4 day post initiation of differentiation of pre-adipocytes.

Insulin is an essential hormone for adipogenesis. GH activates PI3K and ERK signaling pathways similar to that of insulin, therefore, GH was suggested to have similar effects on the initiation and transformation of pre-adipocyte differentiation as insulin [7, 8]. Our previous data showed insulin and GH has synergistic effects on GH induced STAT5 activation [9]. In the present study, We found that in mature adipocyte, GH treatment reduced the expression of C/EBP $\alpha$ and PPAR $\gamma$, which indicated that GH has potentially inhibitory effect on lipid accumation of adipocytes or adipocyte maturation. During adipogenesis, GH intervention resulted in reduced mRNA and protein expression of C/EBP $\alpha$ and PPAR $\gamma$ at day 4 after the initiation of adipogenesis, which indicated that GH has inhibitory effect on adipocyte maturation. We also checked the expression levels of C/EBP $\beta$ and PPAR $\alpha$ in parallel with C/ $\mathrm{EBP} \alpha$ and PPAR $\gamma$ during the process of GH intervention in adipogenesis, but no significance changes were detected (data not shown). Waxman once reported STAT5B activation inhibited PPAR $\gamma$ transactivation [25], while STAT5B is a downstream signaling molecule of $\mathrm{GH}$ receptor. It is possible that GH regulates PPAR $\gamma$ expression by multiple pathways.

FAS and FABP are two genes directly related to adipocyte lipid synthesis. Our data showed that GH intervention during lipogenesis significantly reduced the mRNA levels of $F A S$ and $F A B P, \mathrm{GH}$ intervention markedly reduced the protein expression of FAS at day 4 day after the initiation of adipogenesis. In mice epididymal adipose tissue, the mRNA levels of $F A S$ and $F A B P$ were also decreased significantly with GH intervention..These data indicates that GH inhibits adipocyte maturation and lipid synthesis in mature adipocytes.

The biological role of UCP1 is to uncouple ATP synthesis from respiratory chain, leading to thermal heat production or energy storage reduction in adipose tissue in small mammals and human infants [26]. UCP1 is "brown-fat-specific" and converts nutrient energy directly to heat in brown adipose tissue. In this present study, we found that during the maturation process of F442A adipocytes and in primary adipose tissue, GH intervention markedly increased UCP1 expression, which indicated that GH might endows F442A adipocytes or adipocytes in adipose tissues some features of brown adipocytes.

To determine whether GH is involved in lipolysis, we examined its effects on the expression of HSL and ATGL. HSL is a rate-limiting enzyme for lipolysis, while ATGL plays 


\section{Cellular Physiology Cell Physiol Biochem 2016;39:2135-2148 \\ \begin{tabular}{ll|l} 
and & DOI: 10.1159/000447909 & $\begin{array}{l}\text { O 2016 The Author(s). Published by S. Karger AG, Basel } \\
\text { www.karger.com/cpb }\end{array}$ \\
\hline
\end{tabular} \\ Zhang et al.: GH on Lipid Maturation in Adipocytes}

essential role in the initial step of triglyceride hydrolysis [27]. During adipogenesis of F442A pre-adipocytes, GH treatment showed no obvious effect on the expression of HSL or ATGL. Of note, in animal study, we found that GH was able to enhance the expression of $H S L$ and ATGL in adipose tissues. It is possible that GH may have no direct effect on ATGL and HSL expression, but could increase ATGL and HSL expression in vivo via an indirect way.

In summary, we found that during the process of adipogenesis, $\mathrm{GH}$ decreases the expression of adipogenic genes and increases the expression of UCP1 and adiponectin, which is likely to reduce lipid storage. In mature adipocytes, $\mathrm{GH}$ reduces the expression of important lipid-accumulation related genes such as C/EBP $\alpha$, PPAR $\gamma$, FAS and FABP, but enhances the expression of lipid reduction genes such as adipor2, SOCS2 and adiponectin. These results indicate that $\mathrm{GH}$ negatively modulates adipocyte maturation and lipid accumulation.

\section{Abbreviations}

Adipor1/2 (adiponectin receptor $1 / 2$ ); ATGL (adipose triglyceride lipase); CIS (cytokineinducible SH 2 containing protein); $\mathrm{C} / \mathrm{EBP} \alpha / \beta(\mathrm{CCAAT} /$ enhancer binding protein $\alpha / \beta)$; FABP (fatty acid binding protein); FAS (fatty acid synthase); GH (growth hormone); HSL (hormone-sensitive lipase); PPAR $\alpha / \gamma$ (peroxisome proliferator-activated receptor $\alpha / \gamma$ ); SOCS (suppressor of cytokine signaling); UCP1 (uncoupling protein 1); CoA (coenzyme A).

\section{Acknowledgements}

This study was supported by National Natural Science Foundation of China (NSFC, funded project: 81170814, 81370881, 81501226, 81400843), the Post-doctoral Science Foundation of China (funded project: 21300074312122), Shandong Provincial Natural Science Foundation (No. ZR2014HP033), and Shandong Provincial Medical and Health Science and Technology Development Plan (No. 2015WS0326). We are thankful to Dr SJ Frank from University of Alabama at Birmingham for his instructive suggestions.

\section{Disclosure Statement}

The authors declare that they have no competing interests.

\section{References}

1 Rasmussen MH: Obesity, growth hormone and weight loss. Mol Cell Endocrinol 2010;316:147-153.

2 Goldenberg N, Barkan A: Factors regulating growth hormone secretion in humans. Endocrinol Metab Clin North Am 2007;36:37-55.

3 Jørgensen JO, Møller L, Krag M, Billestrup N, Christiansen JS: Effects of growth hormone on glucose and fat metabolism in human subjects. Endocrinol Metab Clin North Am 2007;36:152-177.

4 Møller N, Copeland KC, Nair KS: Growth hormone effects on protein metabolism. Endocrinol Metab Clin North Am 2007;36:89-100.

5 Rasmussen M, Hvidberg A, Juul A, Main K, Gotfredsen A, Skakkebaek N, Hilsted J, Skakkebae N: Massive weight loss restores 24-hour growth hormone release profiles and serum insulin-like growth factor-I levels in obese subjects. J Clin Endocrinol Metab 1995;80:1407-1415.

6 Vottero A, Guzzetti C, Loche S: New aspects of the physiology of the GH-IGF-1 axis. Endocr Dev 2013;24:96105.

7 Nixon T, Green H: Contribution of growth hormone to the adipogenic activity of serum. Endocrinology 1984;114:527-532.

8 Doglio A, Dani C, Grimaldi P, Ailhaud G: Growth hormone regulation of the expression of differentiationdependent genes in preadipocyte ob1771 cells. Biochem J 1986;238:123-129.

9 Zhang Y, Liu Y, Li X, Gao W, Zhang W, Guan Q, Jiang J, Frank SJ, Wang X: Effects of insulin and IGF-I on growth hormone-induced STAT5 activation in 3T3-F442A adipocytes. Lipids Health Dis 2013;12:56. 


\section{Cellular Physiology Cell Physiol Biochem 2016;39:2135-2148 \begin{tabular}{ll|l} 
and Biochemistry & Published online: November 02, 2016 & $\begin{array}{l}\text { C 2016 The Author(s). Published by S. Karger AG, Basel } \\
\text { www.karger.com/cpb }\end{array}$ \\
\hline
\end{tabular} \\ Zhang et al.: GH on Lipid Maturation in Adipocytes}

10 Berti L, Irmler M, Zdichavsky M, Meile T, Böhm A, Stefan N, Fritsche A, Beckers J, Königsrainer A, Häring HU: Fibroblast growth factor 21 is elevated in metabolically unhealthy obesity and affects lipid deposition, adipogenesis, and adipokine secretion of human abdominal subcutaneous adipocytes. Mol Metab 2015;16:519-527.

11 Pérez MR, Medina-Gómez G: [Obesity, adipogenesis and insulin resistance]. Endocrinol Nutr 2011;58:360369.

12 Palacios-Ortega S, Varela-Guruceaga M, Algarabel M, Ignacio MF, Alfredo MJ, de Miguel C: Effect of TNFalpha on caveolin-1 expression and insulin signaling during adipocyte differentiation and in mature adipocytes. Cell Physiol Biochem 2015;36:1499-1516.

13 Roemmler J, Gockel A, Otto B, Bidlingmaier M, Schopohl J: Effects on metabolic variables after 12-month treatment with a new once a week sustained-release recombinant growth hormone (GH: LB03002) in patients with gh deficiency. Clin Endocrinol 2012;76:88-95.

14 Fain JN, Ihle JH, Bahouth SW: Stimulation of lipolysis but not of leptin release by growth hormone is abolished in adipose tissue from stat5a and b knockout mice. Biochem Biophys Res Commun 1999;263:201-205.

15 Petrov PD, Granados N, Chetrit C, Martínez-Puig D, Palou A, Bonet ML: Synergistic effects of a mixture of glycosaminoglycans to inhibit adipogenesis and enhance chondrocyte features in multipotent cells. Cell Physiol Biochem 2015;37:1792-1806.

16 Clarkson RW, Chen CM, Harrison S, Wells C, Muscat GE, Waters MJ: Early responses of trans-activating factors to growth hormone in preadipocytes: differential regulation of CCAAT enhancer-binding proteinbeta (C/EBP beta) and C/EBP delta. Mol Endocrinol 1995;9:108-120.

17 Kawai M, Namba N, Mushiake S, Etani Y, Nishimura R, Makishima M, Ozono K: Growth hormone stimulates adipogenesis of 3T3-L1 cells through activation of the Stat5A/5B-PPARgamma pathway. J Mol Endocrinol 2007;38:19-34.

18 Rowland JE, Lichanska AM, Kerr LM, White M, d'Aniello EM, Maher SL, Brown R, Teasdale RD, Noakes PG, Waters MJ: In vivo analysis of growth hormone receptor signaling domains and their associated transcripts. Mol Cell Biol 2005;25:66-77.

19 Huo JS, McEachin RC, Cui TX, Duggal NK, Hai T, States DJ, Schwartz J: Profiles of growth hormone (GH)regulated genes reveal time-dependent responses and identify a mechanism for regulation of activating transcription factor 3 by GH. J Biol Chem 2006;281:4132-4141.

20 Yang H, Feng M, Tan X, Yan G, Gan L, Sun C: Construction of suppressor of cytokine signaling 2 (SOCS2) adenoviral overexpression vector and its impact on growth-hormone-induced lipolysis in swine primary adipocytes. Genet Mol Res 2013;12:1283-1293.

21 Esfahani M, Movahedian A, Baranchi M, Goodarzi MT: Adiponectin: An adipokine with protective features against metabolic syndrome. Ira J Basic Med Sci 2015;18:430-442.

22 Lazra Y, Falach A, Frenkel L, Rozenberg K, Sampson S, Rosenzweig T: Autocrine/paracrine function of globular adiponectin: Inhibition of lipid metabolism and inflammatory response in 3T3-L1 adipocytes. J Cell Biochem 2014;116:754-766.

23 Chou IP, Chiu YP, Ding ST, Liu BH, Lin YY, Chen CY: Adiponectin receptor 1 overexpression reduces lipid accumulation and hypertrophy in the heart of diet-induced obese mice-possible involvement of oxidative stress and autophagy. Endocr Res 2014;39:173-179.

24 Rosen ED, Hsu CH, Wang X, Sakai S, Freeman MW, Gonzalez FJ, Spiegelman BM: C/EBPalpha induces adipogenesis through PPARgamma: A unified pathway. Genes Dev 2002;16:22-26.

25 Zhou YC, Waxman DJ: STAT5b down-regulates peroxisome proliferator-activated receptor $\alpha$ transcription by inhibition of ligand-independent activation function region-1trans-activation domain. J Biol Chem 1999;274:29874-29882.

26 Stier A, Bize P, Habold C, Bouillaud F, Massemin S, Criscuolo F: Mitochondrial uncoupling prevents coldinduced oxidative stress: A case study using UCP1 knockout mice. J Exp Biol 2014;217:624-630.

27 Schoenborn V, Heid IM, Vollmert C, Lingenhel A, Adams TD, Hopkins PN, Illig T, Zimmermann R, Zechner $\mathrm{R}$, Hunt SC: The ATGL gene is associated with free fatty acids, triglycerides, and type 2 diabetes. Diabetes 2006;55:1270-1275. 